DOI: https://doi.org/10.47405/mjssh.v6i8.892

\begin{tabular}{|c|c|}
\hline$x_{10}$ & Malaysian Journal of Social Sciences and Humanities (MJSSH) \\
\hline Malaysian Journal of & Volume 6, Issue 8, August 2021 \\
\hline (MJ-SSH) & e-ISSN : 2504-8562 \\
\hline & $\begin{array}{l}\text { Journal home page: } \\
\text { www.msocialsciences.com }\end{array}$ \\
\hline
\end{tabular}

\title{
Warisan Budaya Tidak Ketara Komuniti Cina Peranakan Kelantan: Kajian Kes Upacara Koi Hoi di Kampung Pasir Parit
}

\author{
Eyo Leng Yan', Rosdeen Suboh', Pue Giok Hun² \\ 1Fakulti Seni Kreatif, Universiti Malaya (UM) \\ 2Institut Kajian Etnik, Universiti Kebangsaan Malaysia (UKM) \\ Correspondence: Rosdeen Suboh (kudin@um.edu.my)
}

\begin{abstract}
Abstrak
Keunikan warisan kebudayaan tidak ketara masyarakat multietnik di Malaysia kian terancam oleh modenisasi dan globalisasi yang berlaku dengan lebih pesat berbanding dengan usaha-usaha yang dijalankan untuk melestari dan memperkasakan warisan kebudayaan itu sendiri. Hal ini lebih ketara bila melibatkan komuniti etnik minoriti yang kurang dikenali umum seperti komuniti Cina Peranakan Kelantan. Justeru itu, makalah ini cuba untuk mengupas dan meneliti satu upacara tradisi Cina Peranakan Kelantan yang semakin dilupakan iaitu upacara Koi Hoi. Perbincangan makalah ini adalah kepada sejarah asal-usul, kepercayaan dan amalan upacara tersebut berdasarkan kajian lapangan yang dilakukan di Kampung Pasir Parit di Jajahan Pasir Mas pada tahun 2019. Kajian mendapati upacara Koi Hoi adalah satu upacara tradisi Tao yang diwarisi secara turun-temurun daripada leluhur yang tiba di Tanah Melayu 300 tahun yang lalu. Ia bertitik-tolak daripada sistem kepercayaan tradisi Cina yang berkaitan dengan kewujudan dan pengaruh kuasa supernatural dalam kehidupan seharian seperti dewa-dewi dan keramat. Upacara Koi Hoi dijalankan sebagai satu usaha beramai-ramai oleh penduduk kampung untuk memohon kepada dewa penjaga kampung perlindungan daripada musibah duniawi mahupun gangguan kuasa ghaib, selain mendapatkan keberkatan demi kesejahteraan seluruh warga kampung. Daripada segi penganjurannya, persiapan dan proses kerja upacara Koi Hoi menerapkan juga elemen-elemen budaya tempatan dan melibatkan partisipasi warga kampung daripada latar etnik berlainan. Justeru itu, melihat kepada kerelevanannya dalam konteks pemupukan perpaduan dalam hubungan antara etnik di Malaysia, maka seharusnya warisan upacara Koi Hoi ini dipelihara dan diiktiraf dengan sewajarnya sebagai warisan kebangsaan di bawah Akta Warisan Kebangsaan 2005.
\end{abstract}

Kata kunci: warisan budaya tidak ketara, Taoisme, upacara Koi Hoi, Cina Peranakan Kelantan, Kampung Pasir Parit

\section{Intangible Cultural Heritage of the Kelantan Peranakan Chinese Community: A Case Study of the Koi Hoi Ceremony in Kampung Pasir Parit}

\begin{abstract}
The uniqueness of the intangible cultural heritage of Malaysia's multiethnic community is now threatened by modernisation and globalisation, which is occurring at a much faster rate compared to the efforts carried out to preserve and strengthen the cultural heritage itself. This matter is even more evident when it involves a lesser-known minority ethnic group, namely the Peranakan Chinese community of Kelantan. Therefore, this article seeks to uncover and examine the Koi Hoi ceremony, a traditional
\end{abstract}


Kelantan Peranakan Chinese ceremony that is on the verge of being forgotten. The article discusses the historical origins, the belief and practices of the Koi Hoi ceremony, based on a field work conducted in Kampung Pasir Parit in Pasir Mas district in 2019. The study found that the Koi Hoi ceremony is a traditional Tao ceremony that has been inherited through the generations from ancestors who arrived in the Malay Peninsula about 300 years ago. It derives from a traditional Chinese belief system that revolves around the existence and influence of supernatural powers such as deities and sacred spirits in daily life. The Koi Hoi ceremony is performed as a collective effort by the villagers to seek protection from the patron deities from worldly and other-worldly troubles, in addition to praying for blessings and prosperity for the entire village. Through its preparation and performance, the Koi Hoi ceremony instills elements of local culture and participation of villagers from various ethnic backgrounds. Therefore, looking at its relevance in the context of fostering unity in intercultural relations among ethnic groups in Malaysia, the Koi Hoi ceremony is a heritage that must be preserved and recognised accordingly as a national heritage under the National Heritage Act 2005.

Keywords: intangible cultural heritage, national heritage, Taoism, Koi Hoi ceremony, Kelantan Peranakan Chinese, Kampung Pasir Parit

\section{Pengenalan}

Sebagai sebuah komuniti yang telah lama terbentuk di Malaysia, keunikan komuniti Cina Peranakan Kelantan bukan sahaja daripada segi kebudayaan Cinanya yang kuat dipengaruhi elemen budaya tempatan, tetapi juga daripada segi pengekalan adat tradisi Cina yang tidak lagi diamalkan dalam masyarakat Cina kontemporari. Ini lazim dapat dilihat melalui ritus-ritus dalam upacara perkahwinan, kematian, dan ulang tahun kematian, yang berkait rapat dengan sistem kepercayaan tradisi Cina yang diwarisi secara turun-temurun daripada leluhur yang tiba di Tanah Melayu 300 tahun yang lalu (Pue, 2018). 'Koi hoi' merupakan istilah dialek Hokkien Kelantan yang bermaksud 'langkah api'. Justeru itu, upacara Koi Hoi cenderung disalah anggap sebagai merujuk kepada satu ritus yang lazim dilakukan dalam sesuatu perayaan atau upacara yang lebih besar dalam tradisi Cina suku tersebut, termasuklah perayaan Sembilan Maharaja Dewa (Nine Emperor Gods atau Jiuhuangye) yang popular diamalkan di rantau Asia Tenggara (Cheu, 1993, 1996). Berbeza daripada perayaan Sembilan Maharaja Dewa yang boleh disertai penganut-penganut Tao daripada pelbagai latar belakang dan tempat tinggal, penganjuran dan penyertaan dalam upacara Koi Hoi komuniti Cina Peranakan Kelantan adalah terhad kepada penganut Tao dalam sesebuah komuniti atau kampung yang khusus tanpa melibatkan orang luar. Ini memandangkan upacara Koi Hoi Cina Peranakan Kelantan adalah terpaut kepada kepercayaan dan amalan penyembahan dewa penjaga kampung (patron deity) yang menjadi amalan tradisi kehidupan berkomuniti masyarakat di China sebelum berlakunya Revolusi 1949 (Chia, 1981). Ringkasnya, upacara ini diadakan sebagai satu usaha menjaga keselamatan dan kesejahteraan seluruh kampung dengan memohon bantuan daripada dewa-dewa penjaga kampung tersebut. Mengikut kepercayaan tradisi Taoisme, dewa-dewa penjaga mampu mengusir anasir-anasir jahat seperti hantu atau roh yang berkeliaran di kawasan kampung mereka selain memberi keberkatan kepada semua ahli dan seluruh kawasan kampung yang dijaga (lihat Teng \& Pue, 2021). Seperti yang tergambar dalam namanya, upacara tersebut dilakukan dengan menggunakan api sebagai medium utama.

Walaupun tidak dapat dipastikan dengan tepat bila upacara Koi Hoi ini mula dipraktikkan di Kelantan, sumber-sumber penceritaan lisan yang diperturunkan daripada satu generasi kepada satu generasi dalam kalangan ahli komuniti membayangkan amalan ini telah dilakukan sejak ratusan tahun dahulu. Kini, ia masih diamalkan di beberapa perkampungan Cina Peranakan di Kelantan. Ini termasuklah di Kg. Balai di jajahan Bachok, Kg. Peringat di jajahan Kota Bharu, Kg. Mata Ayer di jajahan Machang, dan Kg. Kasar serta Kg. Pasir Parit di jajahan Pasir Mas. Kebergantungan kepada sumber lisan yang hanya diketahui oleh segelintir ahli komuniti telah menyebabkan upacara Koi Hoi kini kurang dikenali dan difahami oleh komuniti Cina Peranakan Kelantan sendiri, lebih-lebih lagi dalam kalangan generasi muda dan ahli-ahli komuniti yang tidak menetap secara kekal dalam perkampungan itu. Sorotan kajian menunjukkan upacara ini jarang disebut dalam kajian atau penerbitan mengenai komuniti Cina 
Peranakan Kelantan sekalipun. Malah, kajian di peringkat prasiswazah, hanya satu daripada 30 latihan ilmiah yang dianalisis oleh Pue (2017) yang telah menyentuh tentang upacara Koi Hoi iaitu dalam konteks di Kg. Balai di jajahan Bachok (Lim, 1989). Keadaan ini menunjukkan betapa warisan kebudayaan tidak ketara komuniti Cina Peranakan Kelantan kurang dikaji daripada aspek yang berkaitan dengan tradisi kepercayaan berbanding dengan tradisi-tradisi lain seperti pakaian, makanan, bahasa, aktiviti kesenian dan seni bina rumah kediaman. Menyedari hal ini, makalah cuba mengupas keunikan upacara Koi Hoi mengikut kepercayaan dan amalan komuniti Cina Peranakan Kelantan, khususnya dalam konteks bagaimana ia dijalankan dalam persekitaran sosiobudaya masyarakat Kelantan kontemporari yang kian membangun, moden, dan dipengaruhi hegemoni budaya Melayu-Islam masa kini.

\section{Agama Tradisi Cina Peranakan Kelantan}

Cina Peranakan Kelantan adalah satu komuniti yang muncul hasil daripada proses asimilasi antara etnik Cina dengan dua etnik tempatan di Kelantan iaitu Melayu dan Siam. Menggunakan tipologi asimilasi oleh Gordon (1964), pengkaji-pengkaji seperti Pue (2018) dan Mohd Shahrul Imran Lim (2021) berpendapat bahawa proses asimilasi yang dilalui komuniti tersebut melibatkan beberapa dimensi pada satu-satu masa, termasuklah akulturasi yang melibatkan peminjaman elemen-elemen kebudayaan tempatan dalam acuan kebudayaan Cina, dan amalgamasi melalui amalan perkahwinan campur antara etnik Cina dengan wanita tempatan. Dalam jangka masa panjang, proses asimilasi ini telah membentuk komuniti Cina Peranakan Kelantan yang bukan sahaja mirip dengan masyarakat tempatan daripada segi penampilan fizikal tetapi juga cara hidup, misalnya dalam bahasa pertuturan, cara berpakaian, makanan dan aktiviti kesenian (Hanapi Dollah, 1986; Pue, 2018; Tan, 1982; Teo, 2003). Perkongsian cara hidup dan interaksi yang akrab dalam masyarakat Kelantan merentasi garis etnik menyebabkan Cina Peranakan Kelantan turut berkongsi identiti sepunya sebagai 'oghe Kelate' (Pawanteh \& Kuake, 2016; Pue et al., 2019).

Di sebalik pengaruh budaya tempatan yang kuat dalam persekitaran dan kehidupan seharian, pegangan hidup sebahagian besar Cina Peranakan Kelantan masih bertunjangkan kepada falsafah dan kepercayaan tradisi Cina yang diwarisi daripada generasi terdahulu, namun pada masa yang sama diadaptasi mengikut lokaliti masing-masing (Carstens, 1983; Lee \& Tan, 2000). Umumnya, wacana mengenai etnik Cina di Malaysia merujuk gabungan kepercayaan eklektik lagi pragmatis yang merangkumi ajaran Konfusianisme, Buddhisme dan Taoisme ini sebagai 'agama Cina' (Chinese religion) walaupun komuniti itu sendiri tidak mempunyai label yang khusus kepada sistem kepercayaan tradisi mereka (Lee \& Tan, 2000). Dalam kalangan etnik Cina sendiri, ia hanya dirujuk sebagai 'bai shen' dalam bahasa Mandarin yang bermaksud 'worshipping deities' atau penyembahan dewa (Tan, 2000). Sebaliknya, komuniti Cina Peranakan Kelantan didapati membeza-bezakan antara amalan keagamaan tradisi Cina kepada tiga komponen menggunakan istilah Hokkien Kelantan, iaitu 'pai lau lang' (Konfusianisme), 'pai put' (Buddhisme) dan 'pai sin' (Taoisme) (Pue, 2018). Hal ini berlaku kerana penekanan kepada kepercayaan dan penyertaan ahli-ahli komuniti dalam setiap komponen tersebut adalah berbeza-beza mengikut pilihan masing-masing (DeBernardi, 1987; Tan, 2011). Rata-rata daripada mereka berpegang kepada Konfusianisme sebagai tunjang kepada agama tradisi Cina. Ajaran Konfusianisme yang tertumpu kepada cara dan nilai yang perlu diterapkan dalam hubungan antara individu dan lazimnya dijelmakan melalui hubungan kekerabatan, termasuklah dengan ahli keluarga yang telah meninggal dunia. Selain Konfusianisme, ada dalam kalangan ahli komuniti yang cenderung untuk memilih antara Buddhisme dengan Taoisme. Ajaran Buddhisme menekankan kepada perlunya manusia melepaskan diri daripada keterikatan (attachment) kepada kehidupan duniawi untuk mencapai pencerahan. Memandangkan Buddhisme dalam agama tradisi Cina Peranakan Kelantan adalah daripada aliran Theravada Thai sama seperti agama anutan etnik Siam di Kelantan, komponen ini mudah dibezakan daripada komponen Taoisme yang dilihat lebih menyerlah 'kecinaan'nya (Mohamed Yusoff Ismail, 1993, 2010). Falsafah Taoisme pula berkisar kepada bagaimana kehidupan seseorang individu harus berlangsung dalam keadaan yang harmoni dalam masyarakat, alam duniawi dan alam ghaib yang dipercayai wujud dalam satu kosmos yang sama, dengan mempraktikkan jalan yang benar atau 'Tao' (道) (Pue et al., 2021). Dengan perkataan lain, Taoisme merupakan satu kepercayaan tradisi Cina bahawa kehidupan manusia 
boleh diubah dan dipengaruhi melalui kudrat sendiri seperti disiplin, pegangan moral dan usaha kuat, termasuklah melalui bantuan kuasa-kuasa supernatural yang ada dalam kosmos (Pue, 2018).

Sifat pragmatik agama tradisi Cina membolehkan penganut-penganutnya mengadaptasikan elemenelemen kepercayaan tempatan yang bersesuaian. Melalui komponen Taoisme, komuniti Cina Peranakan Kelantan menerapkan elemen-elemen kepercayaan folk yang diamalkan dalam masyarakat tempatan sebelum agama Islam bertapak kukuh dalam masyarakat Kelantan. Ini termasuklah konsep kuasa supernatural dalam kepercayaan folk yang diamalkan masyarakat tempatan sebelum agama Islam bertapak kukuh dalam masyarakat Kelantan, misalnya hantu, keramat dan semangat (Cheu, 1993) serta simbolisme mengikut budaya tempatan seperti dalam konteks pulut kuning (Pue, 2018). Adaptasi mengikut lokaliti turut dapat dilihat dalam Taoisme melalui penjelmaan kuasa supernatural yang digambarkan sebagai orang tempatan seperti dalam fenomena Datuk Kong yang berlaku bukan sahaja dalam komuniti Cina Peranakan Kelantan tetapi masyarakat Cina di rantau Alam Melayu (Cheu, 1998; Chin \& Lee, 2014; Eyo \& Rosdeen, 2019; Tan, 2011).

Elemen-elemen tempatan berkenaan disulam kewujudannya dalam alam ghaib mengikut kepercayaan Taoisme yang digambarkan sebagai mirip kepada alam duniawi masyarakat tradisional di China. Dalam konteks ini, 'masyarakat' alam ghaib turut terdiri daripada pelbagai lapisan hierarki sosial yang diketuai oleh Thi Kong yang bermaksud 'tuhan langit' (Tan, 2018). Golongan dewa di lapisan pertengahan pula berasal daripada manusia (sama ada benar-benar wujud dalam lipatan sejarah, ataupun mitos) yang menunjukkan keperibadian, mempunyai ciri-ciri yang luar biasa atau besar jasanya kepada masyarakat semasa hayatnya, dan diangkat menjadi dewa selepas kematiannya. Antara dewa-dewa yang lazim disembah dalam komuniti Cina Peranakan Kelantan ialah Ma Chor (Mazu), Kuan Tir Kun, Ngo Kok, Tiu Kong Sen Kun, Fa Zhu Gong, Wu Kong, Tua Pek Kong, Heng Tua, Keng Choo, Ji Gong dan Na Zha (Eyo \& Rosdeen, 2019; Teng \& Pue, 2021). Golongan yang mendiami lapisan bawah alam ghaib pula terdiri daripada kuasa-kuasa supernatural yang wujud dalam persekitaran atau lokaliti tertentu termasuk datuk penjaga tanah, Datuk Kong (Lee \& Chin, 2014) dan keramat (Cheu, 1997). Keramat yang menjaga sesuatu benda hidup (seperti pokok) atau benda bukan hidup (misalnya kubur, batu besar dan busut anai-anai) lazimnya dipanggil dengan gelaran 'datuk' (Tan, 2018). Selain daripada tuhan, dewa dan keramat, penghuni alam ghaib turut terdiri daripada pelbagai jenis kuasa supernatural lain seperti hantu dan roh. Seperti juga masyarakat dalam alam duniawi, penghuni-penghuni alam ghaib terdiri daripada kuasa-kuasa supernatural yang baik dan jahat (DeBernardi, 1987). Mengikut kepercayaan Taoisme, manusia dapat meminta bantuan daripada kuasa supernatural yang baik supaya diberikan keberkatan, kesihatan dan kekayaan selain daripada dilindungi daripada segala musibah dan nasib malang.

Bagi Cina Peranakan Kelantan, kuasa supernatural yang penting di peringkat komuniti ialah dewa-dewa. Kepercayaan dan penyembahan dewa-dewa dibawa bersama leluhur Cina Peranakan yang tiba di Kelantan kira-kira 300 tahun dahulu iaitu semasa era Dinasti Qing (Teng \& Pue, 2021). Perjalanan dari China ini perlu menempuh laluan yang berbahaya, justeru mereka membawa bersama arca dewa masingmasing untuk tujuan sembahyang agar diberkati di sepanjang perjalanan (Zinitulniza, 2016). Apabila petempatan dibuka dan komuniti terbentuk, dewa-dewa tersebut diangkat menjadi dewa penjaga kawasan dan penduduk kampung (patron deity) terutamanya dewa-dewa yang menunjukkan unsur-unsur magis. Menurut Teng dan Pue (2021), hal ini berlaku misalnya dalam konteks pemilihan dewa Kuan Tir Kun Kiam Cui Kang bagi Kg. Sering dan dewa Ma Chor di Kg. Ciakkha, yakni dua petempatan tradisional komuniti Cina Peranakan Kelantan yang terletak dalam jajahan Kota Bharu. Selain itu, pemilihan dewa penjaga komuniti Cina Peranakan Kelantan turut dikenal pasti berlaku dengan melibatkan manusia biasa tetapi mempunyai sifat yang luar biasa, dan seterusnya diangkat menjadi dewa selepas kematiannya. Ini dapat dilihat misalnya dalam konteks Pek Wan Chor di Kg. Hunsiau (Tan, 1982; Teng \& Pue, 2021). Satu lagi cara pemilihan dewa penjaga bagi sesebuah komuniti ialah dengan berdasarkan kepada ciri-ciri yang ada pada sesuatu dewa yang ingin dijadikan suri teladan kepada ahli komuniti seperti yang berlaku dalam konteks pemilihan dewa Kuan Tir Kun sebagai dewa penjaga Kg. Chekok di jajahan Pasir Mas (Teng \& Pue, 2021). Peri pentingnya peranan dewa penjaga dalam menjaga keselamatan dan kemakmuran komuniti sekampung menyebabkan kepercayaan dan amalan penyembahan dewa penjaga komuniti tetap wujud biarpun dalam ketiadaan bangunan keagamaan yang khusus seperti tokong di kampung itu. Dalam konteks ini, arca dewa penjaga dijaga secara bergilir-gilir 
dari satu rumah ke satu rumah lain, manakala upacara penyembahan dewa penjaga perlu melibatkan partisipasi daripada seluruh komuniti (Pue et al., 2021; Tan, 1982). Bagi komuniti Cina Peranakan Kelantan, mereka percaya jika dewa penjaga tidak dijaga dengan baik, musibahnya akan terkesan ke atas seluruh kampung dan penduduknya (Pue et al., 2021).

Daripada segi ini, dewa penjaga komuniti dan penyertaan dalam penyembahan dewa penjaga komuniti boleh dilihat sebagai satu penanda identiti komuniti dan ahli-ahlinya (Chia, 1981; DeBernardi, 1987; DeBernardi, 2006; Tan, 1982). Namun begitu, kajian-kajian lepas menunjukkan partisipasi dalam amalan agama tradisi Cina termasuk Taoisme, tidak disertai dengan kefahaman tentang falsafah dan makna yang mendasarinya. Sebagai contoh, ritus-ritus keagamaan seperti membakar colok dan upacara menurun dilihat sebagai aktiviti kolot dan tahyul (superstitious) oleh golongan yang berpendidikan tinggi dan telah biasa dengan cara hidup moden (Goh, 2009; Tan, 2018). Hal yang sama turut berlaku dalam komuniti Cina Peranakan Kelantan khususnya dalam kalangan belia yang “...mulai mempersoalkan agama tradisi... [dan] ...tidak begitu berminat untuk melakukan upacara-upacara tradisi yang berkaitan dengan keagamaan" (Owee, 1987, pp. 163-164). Ketiadaan minat, selain daripada perubahan cara hidup dalam masyarakat kontemporari yang tidak lagi berpusatkan kepada aktiviti komunal seterusnya memberi kesan ke atas kelangsungan upacara keagamaan di peringkat komunal termasuk upacara Koi Hoi.

\section{Metod Kajian}

Penyelidikan kualitatif ini telah dijalankan dengan menggunakan pendekatan kajian kes di mana sesuatu fenomena sosial dapat dicerap secara terperinci bagi tujuan penerokaan, membuat penemuan dan interpretasi menggunakan satu contoh kes yang khusus (Abercrombie et al., 2006, p. 45). Kg. Pasir Parit yang terletak di jajahan Pasir Mas, Kelantan, telah dipilih sebagai kajian kes atas beberapa faktor. Pertama, Kg. Pasir Parit merupakan petempatan tradisional dan antara yang terawal dibuka oleh komuniti Cina Peranakan Kelantan (Teng \& Pue, 2021). Kampung ini juga merupakan petempatan komuniti Cina Peranakan Kelantan yang terbesar dengan saiz populasi kira-kira 2,000 orang (Mohd. Shahrul, 2021). Selain itu, lokasinya yang terletak di tengah-tengah jalan antara Tanah Merah dan Pasir Mas adalah dikelilingi oleh perkampungan Melayu seperti Kg. Chekok, Kg. Jabo, Kg. Bechah Kelubi dan Kg. Kubang Gendang, justeru membolehkan pengaruh hubungan inter-etnik dalam kehidupan seharian dapat diperhatikan (Tan et al., 2018) (Rajah 1). Kg. Pasir Parit turut dipilih sebagai kajian kes memandangkan kebudayaan Cina Peranakan Kelantan masih kuat dipraktikkan dalam kehidupan seharian sehingga kini, misalnya daripada segi bahasa pertuturan, cara berpakaian, makanan dan adat makan, serta adat keagamaan (Mohd. Shahrul, 2021; Tan et al., 2018). Malah, Kg. Pasir Parit merupakan satu daripada segelintir perkampungan Cina Peranakan Kelantan yang masih aktif dalam amalan upacara Koi Hoi.

Data bagi penyelidikan ini dikumpulkan melalui dua cara. Pertamanya, pengarang utama telah menjalankan kutipan data primer di lapangan selama tiga hari di Kg. Pasir Parit di jajahan Pasir Mas, Kelantan pada bulan Februari 2019 bersempena dengan upacara Koi Hoi yang berlangsung pada 15 Februari. Walaupun pendek, tempoh selama tiga hari didapati mencukupi untuk membolehkan pengumpulan data primer mengambil kira aspek sebelum, semasa dan selepas upacara Koi Hoi berlangsung. Kaedah ini mirip kepada pendekatan 'rapid ethnographic assessment' yang membolehkan sesuatu kajian dijalankan dalam tempoh yang lebih pendek tanpa menjejaskan mutu penyelidikan kualitatif dengan bersandarkan kepada prinsip-prinsip kajian etnografi tradisional (Sangaramoorthy \& Kroeger, 2020). Tempoh kajian lapangan turut dapat dikurangkan memandangkan pengarang utama sedia jelas dengan latar belakang dan komuniti Cina Peranakan Kelantan di Kg. Pasir Parit daripada kajian-kajian yang dijalankan sebelum ini (Eyo, 2001, 2014). Justeru itu, masalah akses dan pembinaan rapport dalam kalangan ahli komuniti yang lazim berlaku di permulaan kerja lapangan dapat dibendung dengan baik (Sangaramoorthy \& Kroeger, 2020). 
Rajah 1: Kedudukan Kg. Pasir Parit dalam peta petempatan Cina Peranakan Kelantan

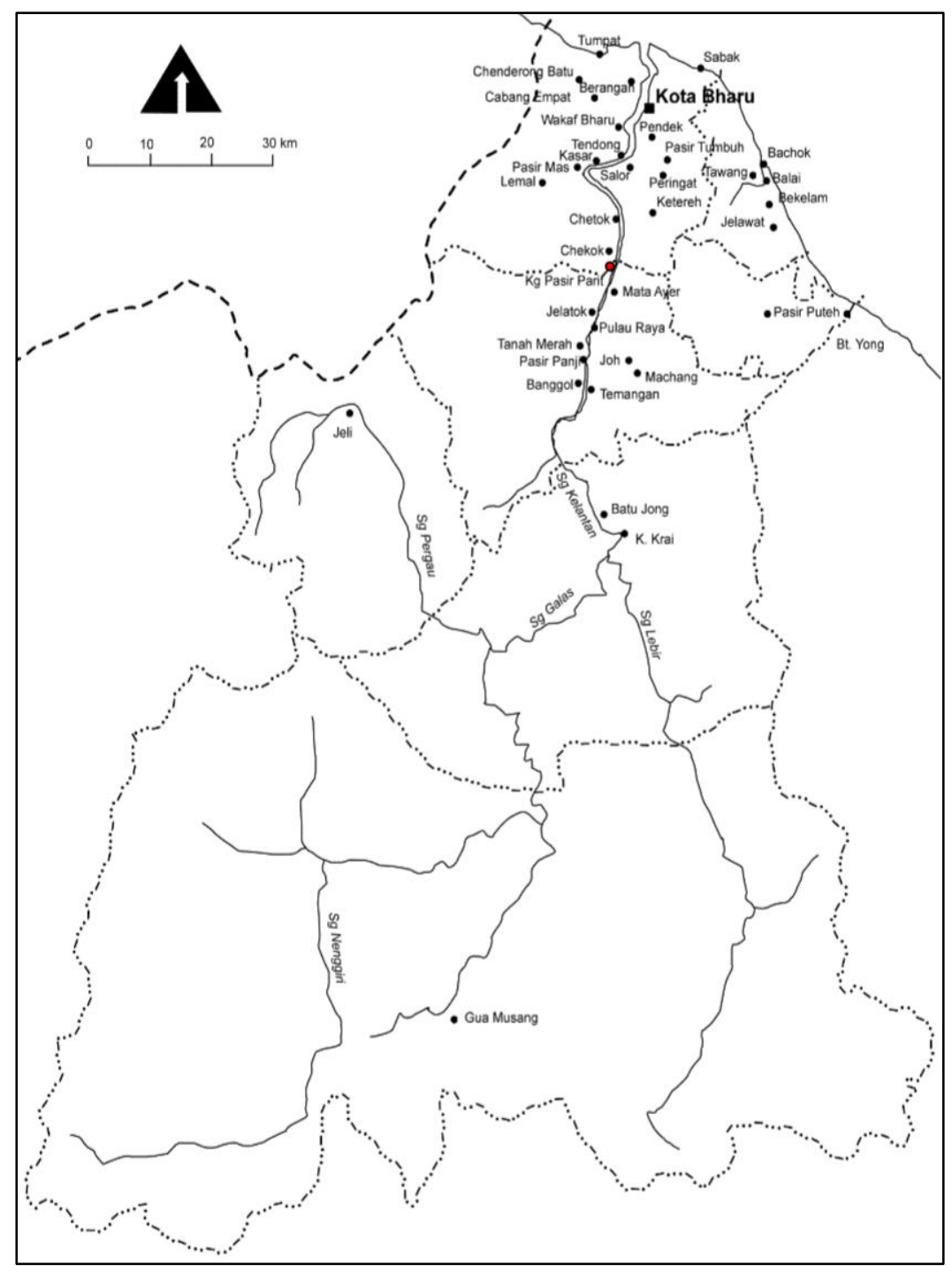

Sumber: Diadaptasikan daripada Jabatan Muzium Malaysia (2014)

Pengumpulan data primer di lapangan dilaksanakan melalui kaedah temu bual dan pemerhatian ikut serta. Temu bual dijalankan ke atas dua kumpulan informan. Kumpulan informan utama (key informants) terdiri daripada tiga orang ahli komuniti yang bukan sahaja anak jati Kg. Pasir Parit, tetapi juga pakar dalam aspek kebudayaan dan sejarah Cina Peranakan Kelantan di kampung tersebut iaitu saudara Ga Ah Chiau, Wee Beng Lee dan Eyo Hock Seng. Semasa kajian lapangan dijalankan, ketiga-tiga informan ini memegang peranan penting dalam upacara Koi Hoi iaitu ketua upacara, pakar adat dan tuan rumah. Bagi kumpulan ini, temu bual berstruktur telah dijalankan berdasarkan senarai soalan yang disediakan merangkumi tema-tema seperti asal-usul upacara Koi Hoi dalam sejarah Kg. Pasir Parit, proses pelaksanaan upacara, penglibatan ahli komuniti dalam upacara dan cabaran-cabaran yang dihadapi dalam menjalankan upacara berkenaan. Bagi informan biasa, persampelan rawak bertujuan (purposive sampling) dilakukan ke atas pengunjung yang hadir pada upacara Koi Hoi untuk mendapatkan reaksi mereka tentang amalan upacara berkenaan daripada perspektif ahli dan bukan ahli komuniti (Babbie, 2010). Untuk itu, tiga informan dipilih untuk mewakili ahli komuniti Cina Peranakan Kelantan Kg. Pasir Parit, etnik Melayu dan etnik Siam. Soalan-soalan bagi informan biasa adalah tidak berstruktur, terbuka dan temu bual telah dilakukan secara spontan. Kaedah pemerhatian ikut serta pula melibatkan penyelidik meneliti upacara yang dikaji melalui perspektif emik dengan meletakkan dirinya sebagai peserta dalam proses penyediaan dan pelaksanaan upacara tersebut. Semua data temu bual dan pemerhatian ikut serta direkodkan dalam bentuk rakaman gambar, video, audio dan nota lapangan. 
Selain daripada data primer, penyelidikan ini turut melibatkan pengumpulan data sekunder berkenaan komuniti Cina Peranakan Kelantan khasnya tentang aspek keagamaan dan upacara Koi Hoi. Sumbersumber data sekunder ini terdiri daripada buku, artikel dalam jurnal, dan tesis yang terdapat di perpustakaan Universiti Kebangsaan Malaysia dan Universiti Malaya. Data primer dan sekunder seterusnya dianalisis secara konseptual dan semantik. Seterusnya, kesahan analisis dilakukan melalui triangulasi dengan mendapatkan maklum balas daripada pihak-pihak berkepentingan dalam penyelidikan ini seperti ahli akademik yang pakar mengenai budaya Cina Peranakan Kelantan, dan pakar keagamaan dan kebudayaan dalam komuniti Cina Peranakan Kelantan Kg. Pasir Parit itu sendiri.

\section{Dapatan Kajian dan Perbincangan}

Dalam konteks kajian ini yang meneliti elemen warisan tidak ketara masyarakat Kelantan sebagai konteks sosio-budaya, komuniti Cina Peranakan Kelantan bukan sahaja dilihat memiliki budaya yang unik, malah komuniti ini juga memainkan peranan yang penting dalam pembangunan dan kelestarian budaya negeri Kelantan. Upacara Koi Hoi dilihat sebagai lambang hubungan antara budaya masyarakatnya. Hubungan antara budaya merujuk kepada kelompok manusia yang mengamalkan kepelbagaian budaya dan agama tetapi mempunyai hubungan yang baik antara satu sama lain. Mereka boleh menerima perbezaan budaya ini dengan rasa hormat dan hidup dalam suasana yang harmoni. Ia merujuk kepada sifat minat terhadap budaya lain, kurang etnosetrik, kemahiran dalam bahasa, mempunyai sensitiviti budaya dan lain-lain (Anderson et al., 2006). Epistemologi hubungan antara budaya di Kelantan boleh difahami dengan meneliti masyarakat Kelantan itu sendiri iaitu dari segi sejarah awal kependudukan masyarakatnya sehingga membentuk masyarakat yang mengalami pertembungan kebudayaan yang berbeza. Pertembungan kebudayaan ini mewujudkan dua kelompok masyarakat iaitu dikenali masyarakat majoriti atau dominan untuk etnik Melayu dan masyarakat minoriti untuk etnik Cina dan Siam, tetapi saling berinteraksi dan hidup dalam suasana yang harmoni.

Buktinya masyarakat Melayu dan Siam yang tinggal di kawasan berdekatan menganggap upacara Koi Hoi ini sebagai sebahagian daripada budaya mereka juga apabila setiap kali tibanya perayaan Tahun Baru Cina, upacara inilah yang sering mereka nanti-nantikan untuk bersama-sama memeriahkan perarakan ini. Menurut pengunjung, Fauzai bin Abdul Halim yang tinggal di Kg. Bechah Kelubi yang terletak tiga kilometer dari Kg. Pasir Parit, dan Ismail bin Ahmad yang berasal dari Tanah Merah, mereka sering menyertai upacara ini sekadar suka-suka kerana melihat ia sebagai upacara yang unik dan meriah. Tambahan pula, mereka telah mempunyai hubungan yang lama dengan komuniti Cina Peranakan di kampung ini. Menariknya, bekalan pelepah kelapa ada yang diambil dari kebun orang Melayu yang berhampiran. Bagi Eyo Hock Seng, penduduk generasi kelima Kg. Pasir Parit, adalah menjadi rutinnya mendirikan unggun api ini dengan bantuan rakan-rakan Melayunya yang sering berkunjung ke rumahnya. Temu bual bersama Wandi A/P Anan iaitu seorang etnik Siam yang tinggal di Kampung Semuba yang terletak enam kilometer dari Kampung Pasir Parit pula menyatakan upacara Koi Hoi telah sebati dalam hidupnya kini setelah berkahwin dengan suaminya yang merupakan Cina Peranakan Kelantan dari Kg. Pasir Parit. Hal ini bermaksud bahawa upacara ini telah menjadi amalan yang dikongsi bersama oleh masyarakat Cina Peranakan itu sendiri, masyarakat Melayu dan juga Siam. Mereka menganggap upacara ini seperti perayaan 'rumah terbuka' bagi masyarakat Cina di sini dan mereka tidak akan segan silu sama-sama menyertainya dan juga memakan juadah yang disediakan. Oleh itu, dapatlah dikatakan bahawa penganjuran upacara ini telah menunjukkan bagaimana masyarakat di Kelantan hidup secara harmoni dengan persefahaman dan saling hormat kepada budaya tempatan tanpa mengira kaum atau agama.

Kejayaan penganjuran upacara ini pada setiap tahun menunjukkan kerjasama dan toleransi antara semua pihak terutamanya daripada masyarakat setempat dan kerajaan tempatan. la secara tidak langsung menjadi satu perantara yang boleh memupuk hubungan antara kaum di Kelantan. Setiap kali penganjurannya, satu permit penganjuran harus dimohon daripada kerajaan tempatan dan permohonan ini akan diluluskan dengan mudah kerana pihak penguatkuasaan telah memahami perjalanan upacara tersebut. Malah, kerjasama daripada polis dan pasukan RELA yang terdiri daripada orang Melayu juga diperlukan untuk mengawal lalu lintas. Upacara Koi Hoi adalah bertepatan dengan semangat saling 
hormat-menghormati antara komuniti, kumpulan dan individu serta memupuk harmoni dan toleransi sebagai asas kepada pembangunan yang mampan antara masyarakat pelbagai kaum di kampung ini dan Kelantan secara keseluruhannya. la melibatkan penglibatan pelbagai budaya dan etnik yang dapat dilihat terutamanya semasa perarakan di sekitar kampung. Semua orang yang hadir tidak kira umur, pekerjaan, etnik ataupun agama boleh hadir dan melihat perarakan tersebut. Upacara ini terbuka kepada semua lapisan masyarakat.

Upacara ini dilihat menyediakan peluang dan suasana sosio-budaya untuk mengekalkan amalan linguistik yang lama. Penduduk Kampung Pasir Parit bertutur dalam dialek Hokkien yang dianggap sangat unik dan berlainan dengan dialek Hokkien negeri-negeri lain di Malaysia. Dialek Hokkien yang dipertuturkan di sini mempunyai percampuran dengan dialek Melayu Kelantan dan Siam tempatan disebabkan faktor percampuran dengan masyarakat Melayu dan Siam. Dalam satu ayat penuh Hokkien, akan diselitkan sama ada dialek Melayu Kelantan atau Siam. Inilah keunikan linguistik masyarakat Cina Peranakan yang tiada di tempat lain (Pue et al., 2019). Bagi Cina Peranakan generasi tua pula, mereka selesa bertutur dalam bahasa Melayu dialek Kelantan sepenuhnya sesama mereka. Dengan kata lain, bahasa Melayu dialek Kelantan dapat terus diwarisi, dikekalkan dan dilestarikan oleh semua etnik di Kelantan hingga kini. Oleh itu, komunikasi bukan menjadi halangan utama bagi masyarakat pelbagai etnik di Kelantan.

Dengan penglibatan pelbagai lapisan masyarakat terutamanya golongan muda dan kanak-kanak sama ada sebagai peserta perarakan atau pembantu upacara membuktikan adat dan budaya ini masih mampu bertahan di kampung ini. Kanak-kanak seawal usia lima tahun telah diajar membantu dalam upacara ini seperti menyediakan bahan-bahan sembahyang, memalu 'beng' dan juga memikul tandu. Ketua upacara juga diwarisi oleh generasi muda, begitu juga dengan juru langkah api juga dipegang peranan oleh golongan muda. Golongan tua di kampung ini boleh menarik nafas lega dan syukur apabila golongan muda berminat untuk mewarisi warisan ini. Hal ini kerana kampung-kampung Cina Peranakan lain sudah semakin berkurangan mengadakan upacara ini disebabkan tiadanya pewaris untuk meneruskan adat dan budaya ini. Kepercayaan yang masih diwarisi secara turun temurun oleh waris mereka dan masih dipelihara serta disembah hingga kini. Bahagian-bahagian selanjutnya makalah ini membincangkan kepercayaan dan cara upacara Koi Hoi yang dicerap melalui kajian lapangan. Istilah-istilah Hokkien Kelantan yang digunakan oleh informan ditandakan dengan simbol ' $\mathrm{H}$ ' dan diterjemahkan kepada istilah Bahasa Melayu yang sesuai. Hasil penyelidikan menunjukkan walaupun berlakunya sedikit pengubahsuaian mengikut arus peredaran masa, hal ini tidak mengubah maksud dan matlamat upacara berkenaan, justeru menunjukkan mereka masih menghormati dan taat kepada tradisi dan identiti kecinaan yang diwarisi (Goh, 2009; Tan, 2018).

\section{Budaya Hidup Upacara 'Koi Hoi'}

Api merupakan antara simbol yang tertua dalam aktiviti keagamaan (Winzeler, 2012). Mengikut kepercayaan tradisi Cina Peranakan Kelantan, api lazim digunakan sebagai 'medium magis' yang signifikan dan simbolik dalam upacara keagamaan (Pue, 2018). Ia bukan sahaja menjadi alat hukuman dan simbol kepada kemusnahan seperti dalam konteks api neraka, tetapi juga sumber kehidupan baharu seperti dalam mitos burung pheonix. Selain itu, api turut digunakan sebagai medium perantaraan untuk 'menghantar' perkakas keperluan kepada si mati oleh anak cucunya dari alam duniawi seperti dalam adat kematian (Pue, 2018). Dalam konteks upacara Koi Hoi, api digunakan sebagai medium magis dewadewa penjaga untuk tujuan 'pembersihan' atau 'penyucian' melalui dua cara, iaitu mengusir anasir-anasir jahat seperti hantu atau roh yang berkeliaran di kawasan perkampungan, dan membersihkan kekotoran yang terlekat pada arca dewa Cina Peranakan Kelantan (Lim, 1989; Teng \& Pue, 2021). Daripada segi ini, pandangan ini menyamai tujuan ritus melangkah api dan air dalam upacara perkahwinan Cina Peranakan Kelantan untuk memastikan 'benda-benda yang tidak diingini' (H: 'mikia bo sui') tidak mengikut mereka masuk ke dalam rumah (Pue, 2018). Selain daripada penyucian, upacara Koi Hoi juga dijalankan untuk menggembirakan dewa-dewa penjaga yang seterusnya diharap akan memberkati seluruh penduduk kampung (Lim, 1989). Apa yang pasti, upacara Koi Hoi hanya dijalankan bagi meraikan dewa penjaga kampung dan tidak kepada dewa-dewa lain. Menurut saudara Ga Ah Chiau selaku ketua upacara Koi Hoi yang ditemu bual, Kg. Pasir Parit mempunyai tiga dewa penjaga iaitu Dewa Kuan Tir Kun yang digelar dengan panggilan Kuan Kong, Dewa Ngo Kok dan Dewa Hong Tek. 
Upacara Koi Hoi dipercayai diwarisi dari nenek moyang terdahulu dan masih diamalkan di beberapa perkampungan Cina Peranakan di Kelantan, termasuklah Kg. Pasir Parit dan Kg. Kasar di jajahan Pasir Mas, Kg. Balai di jajahan Bachok, Kg. Peringat di jajahan Kota Bharu dan Kg. Mata Ayer di jajahan Machang. Namun setakat ini, tidak ada satu fakta yang kukuh tentang bila upacara ini mula dipraktikkan di Kelantan. Menurut penduduk asal Kampung Pasir Parit, Eyu Kam Tiu yang telah menetap di kampung ini sejak hampir 80 tahun yang lalu, upacara Koi Hoi berkemungkinan diadakan sejak 200 tahun dahulu menerusi penceritaan lisan oleh generasi-generasi terdahulu. Garis masa ini turut disokong dalam kajian Teng dan Pue (2021) berkenaan sejarah asal-usul penyembahan dewa penjaga di Kelantan, memungkinkan upacara Koi Hoi yang diamalkan dalam komuniti Cina Peranakan Kelantan diwarisi secara langsung daripada budaya Cina yang dibawa oleh leluhur mereka.

Menurut saudara Wee Beng Lee (71 tahun) yang merupakan anak jati Kg. Pasir Parit dan mantan ketua upacara Koi Hoi, pada asalnya upacara Koi Hoi di Kg. Pasir Parit disambut pada hari keempat Tahun Baru Cina iaitu sejurus selepas upacara 'masuk roh' (H: 'jip sin') dewa yang diadakan pada malam ketiga Tahun Baru Cina iaitu selepas jam 12 tengah malam. Selepas selesai upacara tersebut, penduduk kampung akan berkumpul di kawasan bukit untuk menjalankan upacara Koi Hoi sejurus selepas subuh atau matahari terbit. Kawasan bukit yang dimaksudkan ialah Bukit Panau yang terletak kira-kira tiga kilometer dari Kg. Pasir Parit di mana terletaknya kawasan perkuburan komuniti tersebut. Menjelang matahari terbit, upacara akan dimulakan dengan ritus bersawai oleh seorang Tok Jinjang (H: tang ki) yang merupakan perantara antara manusia biasa dengan kuasa supernatural. Semasa bersawai, diri Tok Jinjang akan dikuasai oleh dewa penjaga $(\mathrm{H}$ : $\sin )$ yang personalitinya terjelma menerusi perwatakanperwatakan yang dikaitkan seperti dewa tersebut. Dewa kemudiannya membuat kertas azimat yang kemudiannya diberi kepada penduduk kampung untuk ditampal pada pintu rumah masing-masing. Selepas selesai tugasnya, dewa keluar dari tubuh Tok Jinjang dan seterusnya bergerak dari satu rumah ke satu rumah melalui ritus perarakan dari satu rumah ke satu rumah.

Sekitar tahun 1980-an, upacara Koi Hoi tidak lagi diadakan di kawasan bukit kerana jauh dari kawasan kampung. Maka, lokasi upacara beralih ke kawasan tepi sungai di Kg. Pasir Parit. Pada masa itu, hari dan proses upacara masih dikekalkan seperti dahulu. Namun dalam tahun 1990-an, upacara Koi Hoi mula dijalankan di rumah. Menurut saudara Wee, hal ini berlaku kerana penduduk kampung tidak mahu lagi bersusah payah untuk membawa segala peralatan sembahyang dan peralatan memasak ke kawasan sungai, dan adalah lebih mudah untuk mengadakan upacara ini di rumah sahaja.

Segala ritus dalam upacara Koi Hoi termasuk ritus perarakan diketuai oleh seorang Ketua Upacara yang pakar dalam adat keagamaan Cina Peranakan Kelantan. Manakala aspek-aspek penganjuran seperti penyediaan peralatan dan keperluan upacara diuruskan oleh seorang Ketua Penganjur ( $\mathrm{H}$ : 'lor $\mathrm{cu}$ '). Jawatan ini terbuka kepada mana-mana ahli komuniti yang berminat dan berkemampuan. Proses pemilihan Ketua Penganjur dilakukan secara undian setahun lebih awal iaitu semasa sambutan hari kebesaran Dewa Kuan Kong pada hari ke-13 bulan lima kalendar lunar. Nama calon-calon Ketua Penganjur ditulis di atas kertas yang kemudiannya digulung kecil dan diletakkan dalam sebuah piring. Nama-nama calon kemudiannya diundi melalui ritus 'puak poi' yang menggunakan alat yang dikenali sebagai 'poi'. Poi diperbuat daripada kayu yang berukuran kira-kira tiga inci lebar dan lima inci panjang. Ia berbentuk seperti buah ginjal yang dibelah dua, dan setiap satunya mempunyai sebelah permukaan yang rata dan sebelah lagi permukaan cembung. Dalam ritus tersebut, individu yang ingin bertanya akan berdiri di hadapan meja sembahyang dengan memegang poi dengan kedua-dua belah tangan. Setelah melafazkan pertanyaan, poi diangkat ke paras dahi sebelum ianya dilepaskan ke permukaan lantai. Kedudukan poi di atas lantai kemudiannya digunakan untuk meramalkan jawapan dewa dalam bentuk jawapan positif (H: 'seng poi') atau negatif (H: 'bo poi') (Rajah 2). Jika kedudukan 'chio poi' diperolehi, ia ditafsirkan sebagai dewa sekadar tersenyum (H: 'chio') dan belum membuat keputusan, justeru ritus 'puak poi' perlu diulang. Dalam pemilihan Ketua Penganjur upacara Koi Hoi, calon yang namanya mendapat bilangan 'seng poi' terbanyak akan terpilih untuk menganjurkan upacara Koi Hoi yang seterusnya. 
Rajah 2: Tafsiran jawapan dewa dalam ritus puak poi (pandangan sisi poi)

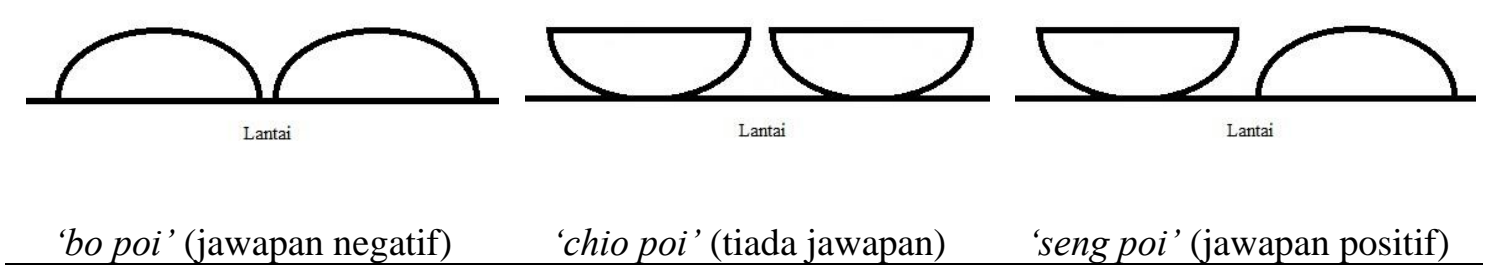

Selepas terbinanya sebuah tokong Cina (H: bio) di Kg. Pasir Parit iaitu Tokong Tir Kun pada tahun 1995, penganjuran upacara Koi Hoi di kampung ini diuruskan oleh Ketua Penganjur dengan bantuan daripada segi pengendalian oleh Persatuan Penganut Tir Kun Kampung Pasir Parit. Justeru, upacara dimula dan diakhiri di tokong tersebut. Selepas upacara ini diambil alih oleh tokong ini, sambutan upacara Koi Hoi telah ditukar ke malam hari ke-15 Tahun Baru Cina iaitu ketika bulan penuh atau terang. Walau bagaimanapun, sejak 20 tahun yang lepas, ia mula diadakan pada hari Jumaat sama ada jatuh pada hari ke-13, ke-14, atau ke-15 Tahun Baru Cina. Hari Jumaat diberi keutamaan berbanding tarikh khusus dalam kalendar lunar merupakan satu contoh penyesuaian tempatan komuniti Cina Peranakan Kelantan. Hari Jumaat dipilih memandangkan ia merupakan hari minggu bagi Kelantan dan penyertaan adalah lebih ramai dari golongan muda dan kanak-kanak. Walaupun tiada sekatan jantina bagi penyertaan dalam upacara ini, lazimnya aspek-aspek ritus melibatkan lebih ramai partisipasi daripada golongan lelaki, manakala golongan wanita lebih cenderung turut serta semasa perarakan dan dalam penyediaan jamuan untuk upacara tersebut. Bahagian seterusnya makalah ini menghuraikan perincian proses kerja upacara Koi Hoi yang telah berlangsung di Kg. Pasir Parit pada tanggal 15 Februari 2019.

\section{Budaya Kerja Upacara 'Koi Hoi'}

Budaya kerja upacara Koi Hoi di Kg. Pasir Parit didapati lebih kurang sama dengan budaya kerja di kampung-kampung Cina Peranakan lain di Kelantan. Namun, kajian lapangan yang dilakukan ke atas upacara ini di Kg. Parit Parit mendapati sambutannya adalah secara sederhana sahaja berbanding dengan kampung lain seperti Kg. Kasar dan Kg. Pasir Mas yang biasanya diiringi dengan tarian singa serta 'yiu kia'. Yiu kia berupa bekas yang diisi minyak dan api akan dibawa bersama semasa perarakan untuk menyalakan api pada unggun api yang didirikan di setiap rumah kediaman penduduk. Upacara ini tidaklah serumit upacara penyembahan dewa penjaga sempena menyambut hari kelahiran atau hari kebesaran dewa penjaga yang diadakan secara besar-besaran justeru memerlukan kos yang tinggi dan persiapan rapi berbulan-bulan lamanya. Sebaliknya, persiapan untuk upacara Koi Hoi disambut sederhana namun meriah. Ia melibatkan dua lokasi yang berlainan iaitu persiapan di tokong itu sendiri dan satu lagi persiapan di rumah masing-masing. Upacara Koi Hoi ini biasanya disertai juga oleh penduduk Cina Peranakan dari kampung lain bagi sama-sama memeriahkan upacara. Malah, ada golongan muda-mudi yang bekerja di luar Kelantan sanggup pulang ke kampung semata-mata untuk memeriahkan sambutan upacara ini.

\section{Persiapan di Tokong Tir Kun}

Persiapan di tokong melibatkan persiapan untuk upacara penyembahan dewa penjaga untuk memohon restu dan berkat, serta persiapan peralatan untuk perarakan pada sebelah malam. Persiapan ini melibatkan beberapa buah tandu ( $\mathrm{H}: k i o)$, alat muzik untuk mengiringi tandu, panji berwarna hitam merah $(\mathrm{H}: k i$ atau or leng) dan juga peralatan keagamaan lain seperti cemeti (H: pat sok). Bahan sembahyang juga adalah ringkas melibatkan manisan untuk menjamu dewa penjaga sahaja. Persiapan bahan keperluan upacara bermula seawal jam 6.30 petang oleh penduduk kampung yang terdiri daripada golongan tua hingga kanak-kanak secara bergotong-royong. Sebelum terbinanya tokong ini, biasanya golongan tua yang akan terlibat dalam persiapan upacara ini, tetapi kini ia telah diambil alih oleh golongan muda mahupun kanak-kanak. Penglibatan daripada golongan muda juga lebih ramai dan dapat memeriahkan lagi upacara. Bagi golongan wanita pula, mereka akan bergotong-royong di bahagian dapur untuk 
DOI: https://doi.org/10.47405/mjssh.v6i8.892

menyediakan nasi air (H: kiam mai) bagi menjamu semua penduduk semasa upacara penutup pada lewat malam. Sejajar dengan amalan budaya Cina Peranakan Kelantan, juadah ini lazim disediakan dalam kuantiti yang banyak sebagai tanda layanan baik dan terima kasih daripada hos kepada pengunjung, tetamu dan sukarelawan pada setiap aktiviti komunal (Pue, 2018).

Rajah 3: Tiga unggun api didirikan di hadapan tokong

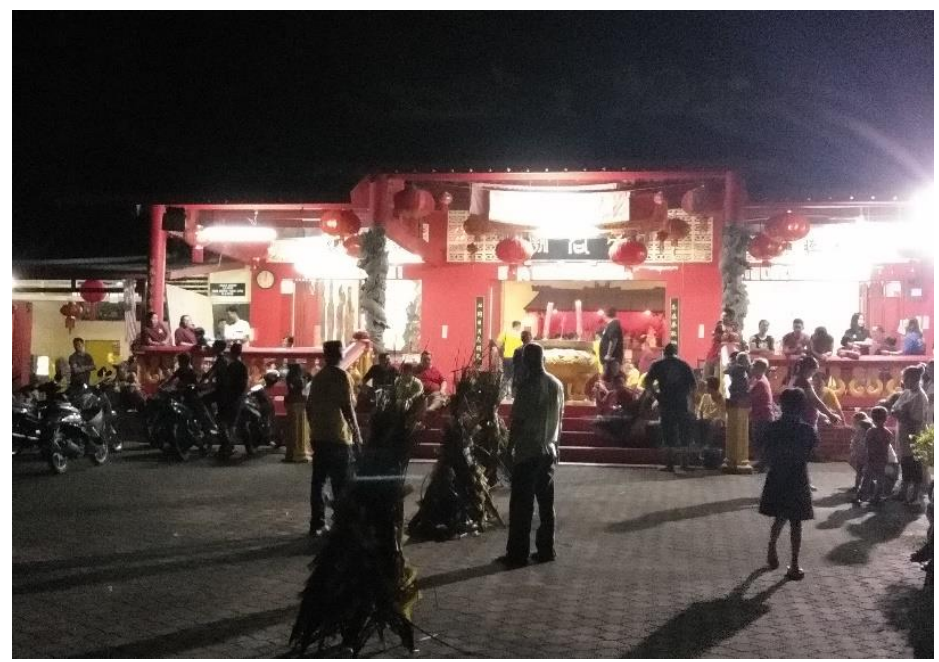

Sumber: Kajian lapangan, Februari 2019

Rajah 4: Arca dewa penjaga diletakkan di atas tandu

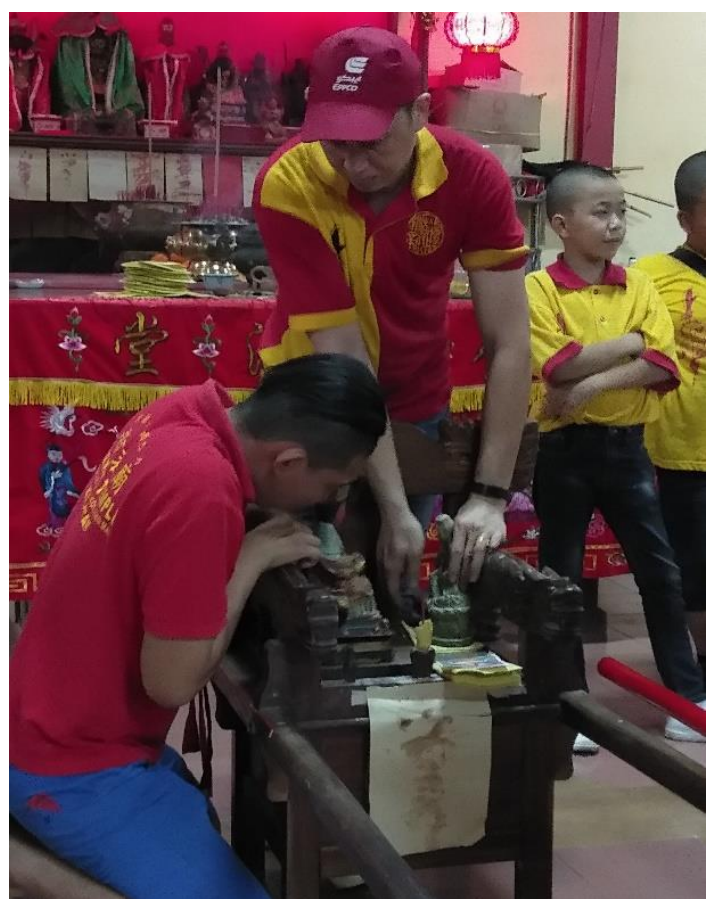

Sumber: Kajian lapangan, Februari 2019

Persiapan dan permulaan upacara Koi Hoi diadakan di tokong. Ketua Penganjur (H: lor $\mathrm{cu}$ ) selaku hos menyediakan tiga buah unggun api (H: hoi tui) di hadapan tokong (Rajah 3). Manakala di hadapan rumah kediaman setiap ahli komuniti didirikan sebuah unggun api. Dalam upacara ini, biasanya dua buah tandu digunakan. Arca (H: kim sin) dewa penjaga komuniti diletakkan di atas tandu (Rajah 4). Apabila dewa penjaga menduduki tandu semasa upacara menurun atau bersawai, ia akan menunjukkan arah jalan kepada pemikul tandu yang akan bergerak mengikut tolakan oleh dewa penjaga. Keterujaan dewa penjaga ini dapat dilihat melalui pergerakan tandu yang semakin pantas. 
Setelah semua tandu dilengkapkan dengan arca dewa penjaga, maka upacara penyembahan dimulakan dengan paluan alat muzik drum kecil yang disebut 'beng' untuk mengiringi perarakan tandu selain dapat menaikkan semangat dewa penjaga. Tandu yang dipikul oleh empat orang lelaki mahupun wanita akan bergerak mencari Tok Jinjang (H: tang ki) sebagai perantara yang akan menzahirkan kehadiran dewa melalui ritus bersawai. Tok Jinjang dibawa ke hadapan meja sembahyang utama. Pada masa ini, seorang Tok Minduk yang merupakan pembantu kepada Tok Jinjang, telah bersedia di sebelah beliau untuk bertindak sebagai juru bahasa dewa dan berkomunikasi dengan dewa yang dizahirkan melalui Tok Jinjang yang dalam keadaan bersawai. Selalunya hanya Tok Minduk yang dapat memahami bahasa yang digunakan oleh dewa. Tok Minduk juga biasanya mempunyai pertalian saudara paling dekat dengan Tok Jinjang seperti anak, adik-beradik atau isteri. Pembantu-pembantu yang lain pula mula membaca mantera (H: chieu) berserta dengan paluan beng untuk menyeru dan menaikkan semangat dewa penjaga. Selain bacaan mantera, asap daripada kemenyan yang dibakar juga memainkan peranan penting dalam proses menurun. Kehadiran dewa penjaga semasa ritus menurun turut dapat diperhatikan daripada perubahan gerakan dan bahasa badan Tok Jinjang yang di luar kawalan Tok Jinjang sendiri, misalnya tangannya menepuk-nepuk meja, seluruh tubuh dan kepalanya terketar-ketar, dan mata menjadi separuh tertutup dan hilang fokus. Setelah dipastikan dewa penjaga telah menguasai diri Tok Jinjang secara sepenuhnya, barulah Tok Minduk memulakan ritus memohon dewa penjaga menyediakan kertas azimat yang ditulis kata-kata suci menggunakan dakwat berwarna merah atau darah untuk ditampal di hadapan pintu setiap rumah. Kertas azimat yang perlu disediakan adalah sama jumlahnya dengan bilangan rumah di kampung ini iaitu dalam 150 keping. Setelah selesai proses penyediaan kertas azimat, dewa penjaga tersebut meninggalkan tubuh Tok Jinjang dan memasuki arca dewa (H: kim sin) di atas tandu. Kemudian, semua penduduk yang terlibat dalam upacara Koi Hoi sama ada sebagai ketua upacara, pemikul tandu, pemukul beng, pemegang panji dan cemeti (berperanan sebagai juru langkah api) perlu menyalakan colok dan menyembah semua dewa penjaga yang terdapat di tokong untuk memohon restu dan berkat agar dilindungi di sepanjang upacara berlangsung.

Ketua Upacara kemudian memohon perkenan dewa penjaga untuk memulakan upacara perarakan dari rumah ke rumah di seluruh Kg. Pasir Parit yang turut ditentukan melalui ritus 'puak poi'. Setelah diperkenankan oleh dewa penjaga, semua tandu dengan dipandu oleh Ketua Upacara, mula berarak dengan diiringi oleh beberapa orang penduduk kampung lain. Perarakan ini pada awalnya hanya disertai oleh beberapa orang penduduk sahaja kerana penduduk lain akan menunggu di rumah masing-masing untuk menunggu ketibaan rombongan perarakan. Jumlah ini akan bertambah sedikit demi sedikit setelah upacara Koi Hoi selesai di setiap rumah kerana mereka akan menyertai rombongan perarakan ini untuk berarak ke rumah yang seterusnya.

\section{Persiapan di Rumah}

Rajah 5: Unggun api yang diselitkan dengan duit kertas emas (H: kim cua)

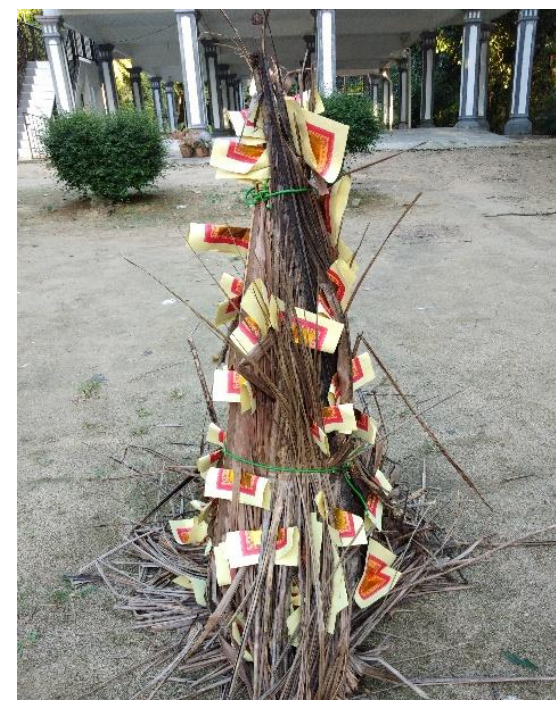

Sumber: Kajian lapangan, Februari 2019 
Di setiap rumah kediaman penduduk, tuan rumah akan menyediakan unggun api yang diperbuat daripada pelepah kelapa kering. Ia dibina secara meninggi berbentuk seperti unggun api. Adalah dipercayai bahawa semakin tinggi unggun api ini dibina, maka semakin banyak rezeki atau tuah (H: ong) yang diperoleh oleh keluarga tersebut. Namun, sewaktu pemerhatian dilakukan, unggun api tersebut dibina rendah dalam lingkungan tiga kaki sahaja untuk memudahkan juru langkah api melangkah api tersebut dan tidak membahayakan keselamatannya. Tambahan pula, ia bagi mengelakkan kecelakaan berlaku disebabkan api yang terlalu marak apabila dibakar. Sehari sebelum upacara ini berlangsung, penduduk kampung biasanya akan mengemaskan halaman rumah dan semua daun disapu bersih. Pelepah kelapa pula dipotong lebih awal, biasanya seminggu lebih awal bagi membolehkan ia kering dan mudah dibakar. Seawal jam empat petang, penduduk kampung mula menaikkan unggun api yang diatur secara menegak, bentuknya seperti gunung dan kemudian diikat supaya berdiri tegak. Kemudian dicelah-celah daun ini akan diselitkan dengan duit kertas emas (H: kim cua) yang digunakan untuk aktiviti penyembahan dewa (rujuk Rajah 5). Unggun api ini didirikan betul-betul di bahagian tengah kawasan lapang berhadapan dengan pintu utama rumah iaitu berhadapan dengan meja sembahyang.

Setelah selesai persiapan di luar rumah, tuan rumah akan mula menyiapkan persiapan di meja sembahyang. Di meja sembahyang akan diletakkan tiga bekas piring kecil yang berisi manisan seperti gula-gula, longan kering, laici kering dan kurma merah kering serta teko kecil berisi teh Cina. Tuan rumah juga akan meletakkan semangkuk air dan semangkuk beras dicampurkan garam (H: iam bi) atas meja sembahyang. Setelah selesai semua persiapan di luar dan di dalam rumah, semua keluarga akan membersihkan diri dan setia menunggu ketibaan rombongan perarakan. Terdapat lebih kurang 100 buah rumah di Kg. Pasir Parit, maka upacara ini biasanya akan berakhir sehingga lewat malam iaitu dalam jam dua belas tengah malam ke jam satu pagi di mana kemuncaknya atau penutupnya akan berakhir di tokong semula.

Rajah 6: Tuan rumah menyembah dewa penjaga untuk memohon berkat di rumah kediamannya

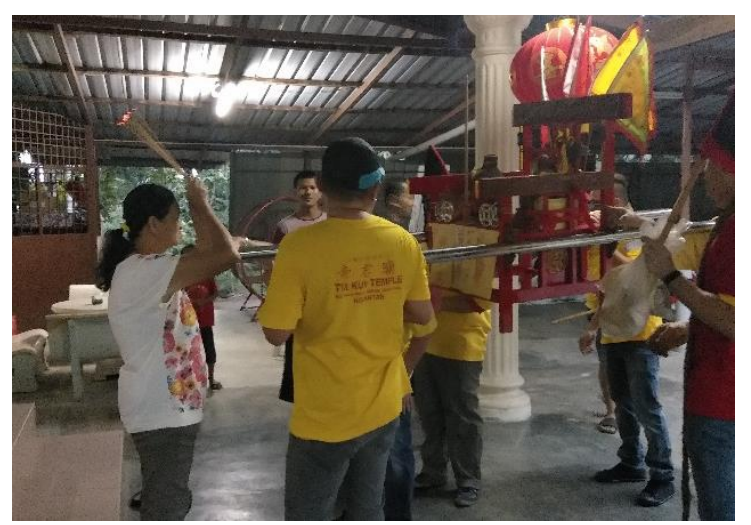

Sumber: Kajian lapangan, Februari 2019

Rajah 7: Juru langkah api bersiap sedia untuk melangkah api setelah ia mula marak

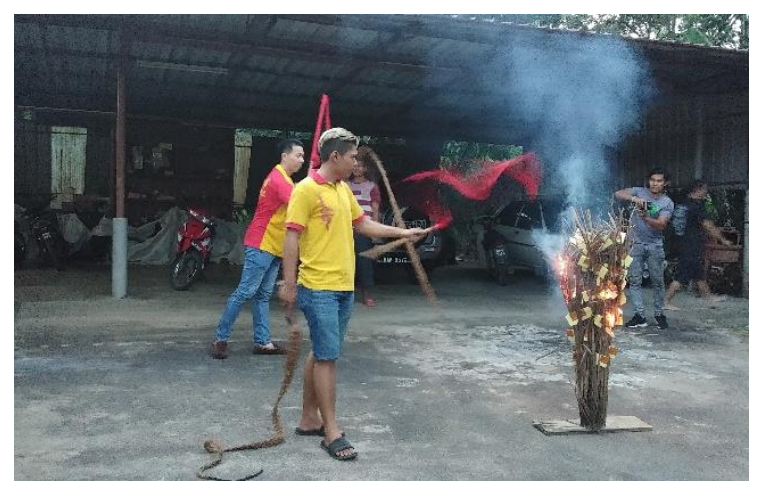

Sumber: Kajian lapangan, Februari 2019 
Isyarat kepada ketibaan rombongan perarakan adalah melalui bunyi paluan 'beng' yang boleh didengari dari jarak dua kilometer. Bunyi paluan 'beng' yang semakin kuat menandakan rombongan hampir tiba. Pada masa ini, tuan rumah akan bersiap-sedia dan memulakan upacara sembahyang 'wajib' iaitu sembah dewa penjaga tanah (H: Tu Ti Kong) di luar rumah dan kemudian masuk ke dalam rumah untuk sembah dewa penjaga. Setelah rombongan tiba, tuan rumah akan membawa Ketua Upacara masuk ke dalam rumah dan menuju ke arah meja sembahyang utama untuk memohon restu dan berkat. Beras dan air yang disediakan di atas meja tadi akan ditambah sedikit dengan beras dan air yang telah dijampi dengan ayat suci serta diletakkan duit kertas emas yang dibakar yang dibawa oleh Ketua Upacara. Beras ini kemudian ditaburkan di serata ruang rumah, manakala air pula direnjis-renjis dari dalam menghala ke luar rumah. Lebihannya disiram pada pokok-pokok di sekeliling rumah. Menurut saudara Ga Ah Chiau, tujuan menabur beras dan merenjis air ini adalah untuk membuang sial (H: soi). Selain itu, air turut berfungsi untuk memberi kesuburan kepada hasil tanaman tuan rumah. Selepas selesai upacara dalam rumah, maka Ketua Upacara akan ke halaman rumah untuk menyalakan api pada unggun yang dibina. Pada masa ini, tuan rumah melakukan penyembahan hormat kepada dewa penjaga yang berada di atas tandu (Rajah 6). Setelah api mula marak, maka paluan 'beng' akan semakin kuat diikuti oleh pemikul tandu bergerak semakin agresif menandakan semangat dewa penjaga sangat teruja dan bersedia untuk melangkah api. Selepas selesai melangkah api (Rajah 7), maka tuan rumah akan menyalakan mercun atau bunga api sebagai tanda tamat sudah upacara Koi Hoi di rumah mereka. Mengikut kepercayaan masyarakat Cina, bunyi mercun ini juga dapat menghalau roh jahat. Selepas itu, rombongan ini akan bergerak ke rumah yang seterusnya.

Terdapat juga tuan rumah yang menyediakan manisan biasanya air sirap, minuman tin, buah-buahan, makanan ringan dan air manisan seperti bubur kacang dan bubur jagung untuk dijamu kepada semua rombongan bagi meraikan tetamu di hari terakhir sambutan Tahun Baru Cina. Dalam upacara ini, dianggarkan seramai seribu orang daripada pelbagai lapisan masyarakat menyertai perarakan termasuklah juga orang Melayu dan Siam. Sewaktu kajian lapangan dijalankan, sambutan upacara Koi Hoi didapati lebih meriah seolah-olah seperti satu pesta keraian apabila turut dipasangkan lagu rancak mengiringi rombongan perarakan. Pembesar suara dan pemain cekera padat dipasang di belakang lori yang dikawal oleh seorang pengacara lagu (disc jockey, $D J$ ) yang berperanan sebagai pengacara majlis. Semua peserta yang menyertai perarakan ini akan sama-sama berjalan kaki mengelilingi kampung yang jaraknya lebih kurang sepuluh kilometer sehingga hentian terakhir di Tokong Tir Kun. Ada segelintirnya yang menaiki motor bagi yang membawa bayi kecil. Kemuncak kepada acara ini ialah pembakaran tiga unggun api di hadapan tokong dan kelihatan tandu-tandu yang dipikul oleh pemikul tandu tadi bergerak semakin agresif, melompat-lompat dan berpusing-pusing menandakan upacara Koi Hoi telah sampai ke kemuncaknya. Selepas selesai upacara ini, semua penduduk yang terlibat dalam upacara ini akan membersihkan diri dengan bersembahyang di meja sembahyang memohon restu dan keberkatan. Semuanya kelihatan kepenatan, namun suasana kemeriahan dan dapat berkumpul beramai-ramai seperti satu keluarga mengatasi segala-galanya. Upacara Koi Hoi pada hari ini berakhir pada jam dua pagi.

\section{Kesimpulan}

Upacara Koi Hoi merupakan warisan budaya Cina Peranakan Kelantan yang dipraktikkan oleh generasi dahulu hingga sekarang. Daripada kupasan di atas, ternyata upacara Koi Hoi yang diamalkan oleh komuniti ini adalah berbeza daripada upacara keagamaan lain dalam tradisi Cina yang turut berkisar kepada penggunaan api sebagai medium magis, misalnya perayaan Sembilan Maharaja Dewa (Nine Emperor Gods atau Jiuhuangye) oleh masyarakat Cina di tempat lain (lihat Cheu, 1993, 1996). Berbalik kepada upacara Koi Hoi, kini ia menjadi tanggungjawab generasi muda untuk mengekalkan tradisi ini yang telah diwarisi sejak 200 tahun yang lalu. Walaupun upacara ini melibatkan penyembahan kepada semangat dewa penjaga yang bertunjang kepada tradisi Cina, ia turut bersifat inklusif kerana dapat menyatupadukan masyarakat pelbagai lapisan umur, latar belakang dan etnik menerusi aktiviti-aktiviti komunal yang dijalankan di luar ruang keagamaan (Tan, 2018). Tujuan upacara Koi Hoi dijalankan juga adalah universal sifatnya, iaitu sebagai satu usaha untuk mendapatkan kehidupan yang lebih baik bukan kepada individu tertentu tetapi kepada seluruh penduduk kampung. Justeru, upacara ini seharusnya dilihat sebagai perayaan kebudayaan dan bukannya keagamaan kerana partisipasi dalam suasana kemeriahan menjadi indikator penting kepada kejayaan penganjurannya (DeBernardi, 2006). Ini telah 
dihuraikan dengan jelas oleh Tan (2011): “[k]esilapan besar dalam pengelasan penganut Cina adalah jangkaan bahawa mereka akan mematuhi secara stereotaip kepada ketiga-tiga agama [Konfusianisme, Taoisme dan Buddhisme] yang sepatutnya merupakan budayanya" (p. 98). Selain itu, apabila dilihat kepada upacara ini pada hari ini yang telah dibuat secara sederhana dan disertai dengan percikan bunga api, bunyi mercun dan tarian singa, ia dilihat telah mengalami perubahan sedikit demi sedikit untuk disesuaikan dengan keadaan semasa. Perubahan pemilihan masa penganjuran pada sebelah malam hari Jumaat berbanding dengan amalan terdahulu yang diadakan di sebelah siang pada hari keempat Tahun Baru Cina juga menunjukkan masyarakat setempat di sini menginginkan penyertaan yang lebih ramai daripada golongan muda dan kanak-kanak supaya dapat memeriahkan lagi sambutan upacara Koi Hoi ini (Tan, 2018).

Melihat kepada kerelevanannya pada hari ini, maka seharusnya warisan ini dipulihara, dipelihara, dikekalkan dan dilestarikan ke peringkat global agar semua masyarakat Malaysia khasnya dan masyarakat dunia umumnya mengenali warisan komuniti Cina Peranakan Kelantan yang diwarisi hingga ke hari ini. Upacara ini juga dilihat perlu diangkat sebagai Warisan Kebangsaan setaraf dengan perayaan utama lain seperti upacara Wangkang yang telah diiktiraf sebagai Warisan Kebangsaan bawah Akta Warisan Kebangsaan 2005 (Akta 645) pada 28 November 2017 dan kemudian mendapat pengiktirafan peringkat UNESCO pada tahun 2020 (Jabatan Warisan Negara, 2021). Pengiktirafan ini amat penting bagi membolehkan upacara ini dikategori sebagai butiran warisan yang harus dipulihara, dipelihara dan dikekalkan melalui pelan perlindungan negara (safeguarding plan).

\section{Rujukan}

Abercrombie, N., Hill, S., \& Turner, B. S. (2006). The Penguin dictionary of sociology (Edisi ke-5). Penguin Books.

Anderson, P. H., Lawton, L., Rexeisen, R. J., \& Hubbard, A. C. (2006). Short-term study abroad and intercultural sensitivity: A pilot study. International Journal of Intercultural Relations, 30(4), 457469.

Babbie, E. (2010). The practice of social research (Edisi ke-12). Wadsworth.

Carstens, S. A. (1980). Pulai: memories of a gold mining settlement in Ulu Kelantan. JMBRAS, 53(1), 50-67.

Carstens, S. A. (1983). Pulai Hakka Chinese Malaysian: a labyrinth of cultural identities. Dlm. P. Gosling \& L. Y. C. Lim (Pnyt.), The Chinese in Southeast Asia: identity, culture and politics (hlm. 79-98). Maruzen Asia.

Cheu, H. T. (1996). The festival of the Nine Emperor Gods in Malaysia: myth, ritual, and symbol. Asian Folklore Studies, 55, 49-72.

Cheu, H. T. (1997). Malay keramat, Chinese worshippers: The sinicization of Malay keramats in Malaysia. National University of Singapore.

Cheu, H. T. (1998). The renicization of Malay keramats in Malaysia. JMBRAS, 71(2), 29-61.

Cheu, H. T. (pnyt.). (1993). Chinese beliefs and practices in Southeast Asia. Pelanduk Publications.

Chia, A. Y. (1981). Pemujaan dewa penjaga: satu kajian kes di Kampung Kasar, Pasir Mas, Kelantan. Latihan ilmiah, Universiti Kebangsaan Malaysia.

Chin, Y. M., \& Lee, Y. F. (2014). Settling down spiritually: Chinese Malaysian's worship of Datuk Gong. Pertanika Journal of Social Science and Humanities, 22(3), 379-391.

DeBernardi, J. (1987). The God of War and the vagabond Buddha. Modern China, 13(3), 310-332.

DeBernardi, J. (2006). The way that lives in the heart: Chinese popular religion and spirit mediums in Penang, Malaysia. Stanford University Press.

Eyo, L. Y. (2001). Tinjauan aspek keagamaan dan kepercayaan Masyarakat Cina Peranakan. Kajian kes: Kampung Pasir Parit, Pasir Mas, Kelantan. Latihan ilmiah, Universiti Kebangsaan Malaysia.

Eyo, L. Y. (2014). Seni persembahan tradisional Kelantan: Hubungan etnik dan perkongsian budaya. Tesis Sarjana, Universiti Kebangsaan Malaysia.

Eyo, L. Y., \& Rosdeen, S. (2019). Beliefs of the sacred spirit: a study of possessed ceremony in Kelantanese Village. International Journal of Management and Applied Science (IJMAS), 5(2), 4147. 
Goh, D. P. S. (2009). Chinese religion and the challenge of modernity in Malaysia and Singapore: syncretism, hybridisation and transfiguration. Asian Journal of Social Science, 37, 107-137.

Gordon, M. M. (1964). Assimilation in American life: The role of race, religion and national origins. Oxford University Press.

Hanapi Dollah. (1986). Asimilasi budaya: kajian kes komuniti Cina di Kelantan. Penerbit Universiti Kebangsaan Malaysia.

Helle, H. J. (2017). China: Promise or threat? A comparison of cultures. Brill.

Jabatan Muzium Malaysia. (2014). Peta penempatan Cina Peranakan Kelantan di sepanjang Sungai Kelantan. Bahagian Perkhidmatan Muzium, Jabatan Muzium Malaysia. Tidak diterbitkan.

Jabatan Warisan Negara. (2021). Ong Chun /Wan Chuan /Wankang ceremony rituals and related practices for maintaining the sustainable connection between man and the ocean. For Inscription on the Representative List of the Intangible Cultural Heritage of Humanity In 2020. Tidak diterbitkan.

Lee, K. H., \& Tan, C. B. (pnyt.). (2000). The Chinese in Malaysia. Oxford University Press.

Lee, Y. F., \& Chin, Y. M. (2014). Datuk Kong worship and Chinese religion in Malaysia: reflections of syncretism, pragmatism and inclusiveness. Dlm. C. B. Tan (pnyt.), After migration and religious affiliation: religions, Chinese identities and transnational networks (hlm. 147-165). World Scientific Publishing.

Lim, A. T. (1989). Perayaan pemujaan Hock Teck Cheng Sin: satu kajian kes di Kampung Balai, Bachok, Kelantan. Latihan ilmiah, Universiti Kebangsaan Malaysia.

Mohamed Yusoff Ismail. (1993). Two faces of Buddhism: Chinese participation in the Thai temples in Kelantan. Dlm. H. T. Cheu (pnyt.), Chinese beliefs and practices in Southeast Asia (hlm. 165-183). Pelanduk Publications.

Mohamed Yusoff Ismail. (2010). Buddhism in a Muslim state: Theravada practices and religious life in Kelantan. The Muslim World, 100, 321-336.

Mohd. Shahrul, I. L. A. (2021). Identiti etnik minoriti Cina Peranakan Kelantan sebagai identiti masyarakat multietnik Malaysia. Tesis PhD., Universiti Kebangsaan Malaysia.

Owee, K. J. (1987). Perubahan adat-resam di kalangan masyarakat Cina Kelantan dalam abad ke 20. Kajian kes di Pasir Mas Kelantan. Latihan ilmiah, Universiti Kebangsaan Malaysia.

Pawanteh, M. R., \& Kuake, J. B. (2016). Orghe Kelantan: a preliminary study. International Journal of Culture and History, 2(4), 184-188.

Pue, G. H. (2017). Engagement of undergraduate students as custodians in heritage conservation enrichment. Kajian Malaysia, 35(Supp. 1), 141-163.

Pue, G. H. (2018). Cina Peranakan Kelantan menerusi lensa sosiologi. UKM Press.

Pue, G. H., Loo, H. C., \& Teng, K. L. (2021). Deconstructing ethnic identity formation and negotiation among the Taoist in contemporary Kelantan: the case of HSBK2019 The 12th International Malaysian Studies Conference (MSC12), Bangi.

Pue, G. H., Ong, P. L., \& Loo, H. C. (2019). Kelantan Peranakan Chinese language and marker of group identity. GEMA Online® Journal of Language Studies, 19(2), 33-51.

Sangaramoorthy, T., \& Kroeger, K. A. (2020). Rapid ethnographic assessments: a practical approach and toolkit for collaborative community research. Routledge.

Tan, C. B. (1982). Peranakan Chinese in northeast Kelantan with special reference to Chinese religion. JMBRAS, 55, 26-52.

Tan, C. B. (2000). Socio-cultural diversities and identities. Dlm. K. H. Lee \& C. B. Tan (pnyt.), The Chinese in Malaysia (hlm. 37-70). Oxford University Press.

Tan, C. B. (2011). Agama Cina di Malaysia: satu pandangan umum. Jurnal Terjemahan Alam \& Tamadun Melayu, 2(2), 96-122.

Tan, C. B. (2018). Chinese religion in Malaysia: temples and communities. Brill.

Tan, Y. S., Ngah, K., \& Darit, S. M. (2018). Formation and negotiation of identity: the case of the Kelantan Kampung Pasir Parit Peranakan Chinese. Asian Ethnicity, 19(1), 16-35.

Teng, K. L., \& Pue, G. H. (2021). Penceritaan lisan jambatan kesinambungan warisan budaya: pendokumentasian asal-usul dewa penjaga dalam kepercayaan agama Tao di Kelantan The 12th International Malaysian Studies Conference (MSC12), Bangi.

Teo, K. S. (2003). The Peranakan Chinese of Kelantan: a study of the culture, language and communication of an assimilated group in Malaysia. Asean Academic Press. 
Malaysian Journal of Social Sciences and Humanities (MJSSH), Volume 6, Issue 8, (page 28 - 44), 2021

$$
\text { DOI: https://doi.org/10.47405/mjssh.v6i8.892 }
$$

Wee, K. H. (1987). Kelantan and the Chinese Kelantanese. Dlm. Nik Hassan Shuhaimi Nik Abd. Rahman (Pnyt.), Kelantan zaman awal: kajian arkeologi dan sejarah (hlm. 216-228). Perbadanan Muzium Negeri Kelantan.

Winzeler, R. L. (2012). Anthropology and religion: What we know, think, and question (Edisi ke-2). AltaMira Press.

Zinitulniza, A. K. (2016). Peranakan Cina Kelantan: sintesis Cina Tanah Besar dan Melayu Tanah Melayu. Institut Terjemahan \& Buku Malaysia. 